\title{
Affordable Walling Materials Used in Low Income Estates of Eldoret, Kisumu and Nakuru Towns in Kenya
}

\section{Clement Kiprotich Kiptum", Victor Muroki Mwirigi, Ochillo Ochieng Steve}

Department of Civil and Structural Engineering, School of Engineering, University of Eldoret, Eldoret, Kenya

Email address:

chelalclement@yahoo.com (C. K. Kiptum),mwirigivictor012@gmail.com (V. M. Mwirigi), ochilosteve@gmail.com (O. O. Steve)

${ }^{*}$ Corresponding author

\section{To cite this article:}

Clement Kiprotich Kiptum, Victor Muroki Mwirigi, Ochillo Ochieng Steve. Affordable Walling Materials Used in Low Income Estates of Eldoret, Kisumu and Nakuru Towns in Kenya. American Journal of Science, Engineering and Technology. Vol. 5, No. 2, 2020, pp. 56-60. doi: $10.11648 /$ j.ajset.20200502.11

Received: March 7, 2020; Accepted: March 20, 2020; Published: April 14, 2020

\begin{abstract}
In today's building industry, availability of cheaper construction materials still remains the primary goal of any developer. In Kenya, bricks, iron sheets, mud and cement/stone blocks are some of the walling materials in use. A newly introduced material which is affordable is Expanded Polystyrene (EPS). This study aimed to evaluate types of walling materials used in low income areas of three major towns of Eldoret, Kisumu and Nakuru in Kenya with a view of determining the awareness levels of EPS. The methodology involved interview questionnaires administered to 77 respondents (landlords and tenants) in poor sub-urban areas of the three towns. The results showed that $56 \%$ of respondents lived in brick houses while a $4 \%$ lived in stone houses and the remaining $40 \%$ lived in houses made of mud or iron sheets. More than $80 \%$ of respondents were not comfortable in the houses they were staying and they hoped for improvement. That is why $94.8 \%$ were ready to pay more if their current living conditions were improved by their plot owners. The highest awareness of EPS use was in Kisumu (60\%), followed by Nakuru (37.5\%) and Eldoret at 33.3\%. The most expensive rooms were those made of stones at KES. 500,000 while mud walled rooms were the least expensive to construct at KES. 35,000. Future research on relationship between distance to source of walling material and preference is recommended.
\end{abstract}

Keywords: Bricks, Expanded Polystyrene Awareness, Landlords, Mud, Tenants, Walling

\section{Introduction}

House affordability depends on cost of land and cost of actual construction. The cost of land in Kenya is extremely high particularly in urban areas and cities like Nairobi [1]. The cost of construction depends again on the source of finances and the cost of building materials. Materials can be sourced locally or are transported from distant places. Use of non-local materials increases the cost of building in Kenyan Shillings (KES). KES can be converted to US dollars by using the exchange rate of 1 US\$ = KES. 102.

The growth of middle class in Kenya and in Africa as whole means that the demand for housing is increasing and hence the need for affordable housing not only for the middle class but also for low income earners. In fact, $80 \%$ of Kenyans are income poor or on the poverty line with increasing poverty trends being witnessed in peri-urban areas [2]. This is worsened by the fact that $60 \%$ of urban dwellers in Kenya live in slums (low income estates) [3].

It is anticipated that by 2030 , more than half of Kenyans will be living in urban areas [4] and as a consequence the demand for housing will increase. This therefore calls for increase in supply of houses to meet the rising demand. With this realization the Kenyan government embarked on housing initiative targeting the low income earners in 2007. Vision 2030 First Medium Term Plan target of 200,000 realized a paltry 3000 units corresponding to a missed target of $98.5 \%$ and that is why there is still housing deficit of 2 million housing units [5]. This is unconstitutional in Kenya where right to housing (Article 23) is enshrined in the constitution 2010.

In his second term, President Uhuru Kenyatta came up with four agendas popularly known as the "Big Four" to guide his development agenda with affordable housing as one of them and this time the a target of 500,000 new affordable homes was set [7]. The huge task can be achieved with 
support from every Kenyan and hence the need for this study as it contributes to the government Big Four Agenda on affordable housing.

In 2015, the cost of building a low cost and low rise building was around KES. 29,000 per square metre for areas outside Nairobi city [8]. Therefore, if one is to construct a two-bed roomed house of say $80 \mathrm{~m}^{2}$ will cost around KES. 2.3 million. Since $72 \%$ of Kenyans earn around KES. 15000 to 49,000 per month [9] means that a person earning KES 15,000 will take 13 years to construct one bed room house assuming all what is earned is used for building. This therefore means that house affordability will remain unattainable unless new technologies are embraced in building of houses.

Such new technologies include interlocking blocks made from earth, expanded polystyrene (EPS) and bricks. Though use of burnt bricks can reduce costs, it is being discouraged as it leads to depletion of forest as firewood is needed to fire kilns for brick making. The use of EPS results in reduction of costs by $25 \%$ and construction time by $50 \%$ and therefore this is ideal building material for the low income earners. Expanded polystyrene (EPS) is a non-biodegradable material that contains $98 \%$ air and $2 \%$ polystyrene and therefore it is light. The density of EPS varies from $10 \mathrm{~kg} / \mathrm{m}^{3}$ and $35 \mathrm{~kg} / \mathrm{m}^{3}$. It is known to have good thermal, sound and water resistance [10].

Research on affordable housing has been on the rise as done by $[3,11,12]$. The researchers did their work on general affordability and did not focus on the poor living in suburban areas. Since EPS is a recent walling material there was need to evaluate the use of different walling materials in low income areas of Eldoret, Kisumu and Nakuru with a view of assessing the level of awareness and acceptance of EPS in the three towns.

\section{Methodology}

\subsection{Study Area}

The research was conducted in three towns of Eldoret, Kisumu and Nakuru in Kenya (Figure 1). Eldoret is in Uasin Gishu County with a population of 163 186, Kisumu in Kisumu County with population of 1155574 and Nakuru town in Nakuru County with a population of 2162202 [13].

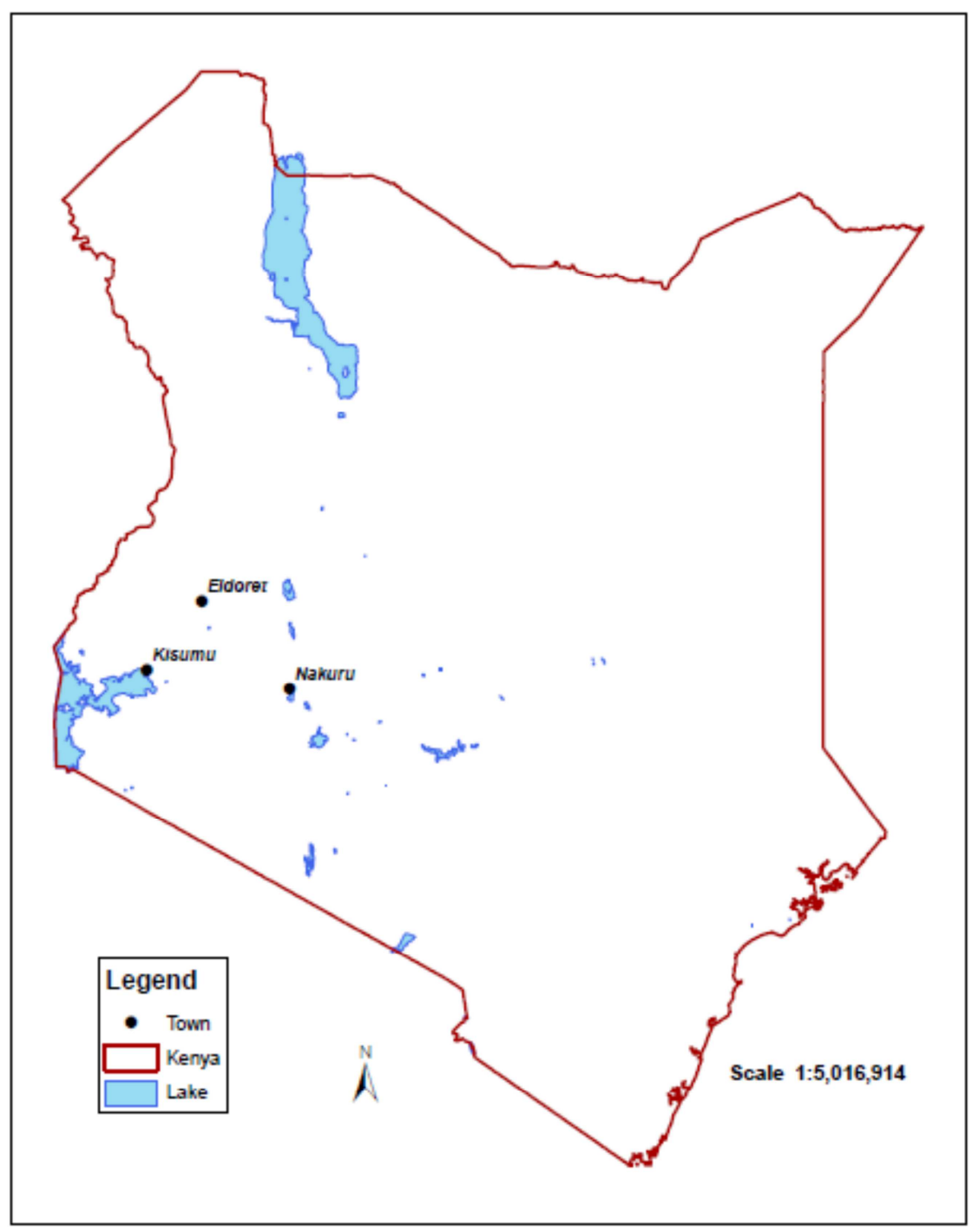

Figure 1. Map of Kenya showing research areas. 


\subsection{Sampling and Data Collection}

Sample of 77 respondents living in low income areas of Eldoret, Kisumu and Nakuru was selected. The respondents from Eldoret were 15, Kisumu were 30 and in Nakuru were 32. Interview questionnaires were administered to plot owners and tenants in the three towns. The selection of the target plot owners was done randomly using snowballing method.

Each questionnaire was divided into two: personal information like gender and other parts. Other parts included number of rooms per plot, cost of one room of approximately
$20 \mathrm{~m}^{2}$, acceptance of EPS, their comfort in the rooms they were staying, rent per room. Pre-testing of questionnaires was done in Kamukunji sub-urban area of Eldoret town. Data collected was analyzed using Microsoft Excel to determine the means and percentages and presented in form of tables and figures.

\section{Results and Discussion}

The results from the interview questionnaires are presented in Table 1.

Table 1. Questionnaire information.

\begin{tabular}{|c|c|c|c|c|}
\hline Description & Categories & Eldoret & Kisumu & Nakuru \\
\hline \multirow{2}{*}{ Gender } & Male & 11 & 21 & 20 \\
\hline & Female & 4 & 9 & 12 \\
\hline \multirow{2}{*}{ Ownership } & Tenant & 10 & 20 & 22 \\
\hline & Owner & 5 & 10 & 10 \\
\hline \multirow{5}{*}{ Walling material } & Iron sheets & 3 & 7 & 10 \\
\hline & Mud & 2 & 5 & 1 \\
\hline & Bricks & 5 & 17 & 21 \\
\hline & Iron sheets/mud & 3 & 0 & 0 \\
\hline & Stone & 2 & 1 & 0 \\
\hline \multirow{3}{*}{ Number of rooms } & Least & 3 & 5 & 5 \\
\hline & Average & 10 & 14 & 11 \\
\hline & Maximum & 20 & 30 & 21 \\
\hline \multirow{3}{*}{$\begin{array}{l}\text { Rent per room (Kenya } \\
\text { Shillings) }\end{array}$} & Least & 800 & 1500 & 1500 \\
\hline & Average & 2607 & 3549 & 3039 \\
\hline & Maximum & 5000 & 7000 & 5000 \\
\hline \multirow{5}{*}{$\begin{array}{l}\text { Cost of room (Kenya } \\
\text { Shillings) }\end{array}$} & Mud/iron sheets & 35,000 to 80000 & & 80000 \\
\hline & Bricks & & 100,000 to 500,000 & 100,000 to 380,000 \\
\hline & Iron sheets/bricks & & & \\
\hline & Iron sheets & 150,000 & 100000 to 125000 & 100000 \\
\hline & Stone & 500000 & & \\
\hline \multirow{2}{*}{ Comfortable of rooms } & No & 10 & 24 & 28 \\
\hline & Yes & 5 & 6 & 4 \\
\hline \multirow{2}{*}{ EPS knowledge } & No & 10 & 12 & 20 \\
\hline & Yes & 5 & 18 & 12 \\
\hline \multirow{2}{*}{ Willingness to pay more } & No & 2 & 1 & 1 \\
\hline & Yes & 13 & 29 & 31 \\
\hline \multirow{2}{*}{$\begin{array}{l}\text { Agreeing to stay in EPS } \\
\text { house }\end{array}$} & No & 0 & 0 & 1 \\
\hline & Yes & 15 & 30 & 31 \\
\hline
\end{tabular}

In Table $1,32.4 \%$ of the respondents were women with Nakuru having the highest percentage of women responding and Kisumu had the least. Further $32.4 \%$ of the respondents were plot owners (landlords/land ladies) with Eldoret and Kisumu having the same percentage of landlords and Nakuru having a slightly lower value.

The walling materials used in the three towns are shown in Figure 2. Most respondents rent or own houses made of bricks $(56 \%)$, followed by iron sheets $(26 \%)$, then mud $(10 \%)$, lastly stone house (4\%) and iron sheets/mud (4\%). Mud houses if not maintained can be a breeding places for jiggers as pointed out by [14]. Some developers prefer iron- sheet walling as its construction is straightforward [15]. The percentages of houses made of bricks were $44 \%, 60 \%$ and $66 \%$ in Eldoret, Kisumu and Nakuru, respectively. Prevalence of bricks was attributed to availability of bricks in the low income areas. In Kenya, low income areas were initially water logged lands because of clay soils. Therefore, purchase price of the plots are low, and hence the reason why many low income people inhabit them. It is interesting to note that the preference of mud was due to the fact that the owners can construct themselves and therefore don't incur labour cost. 


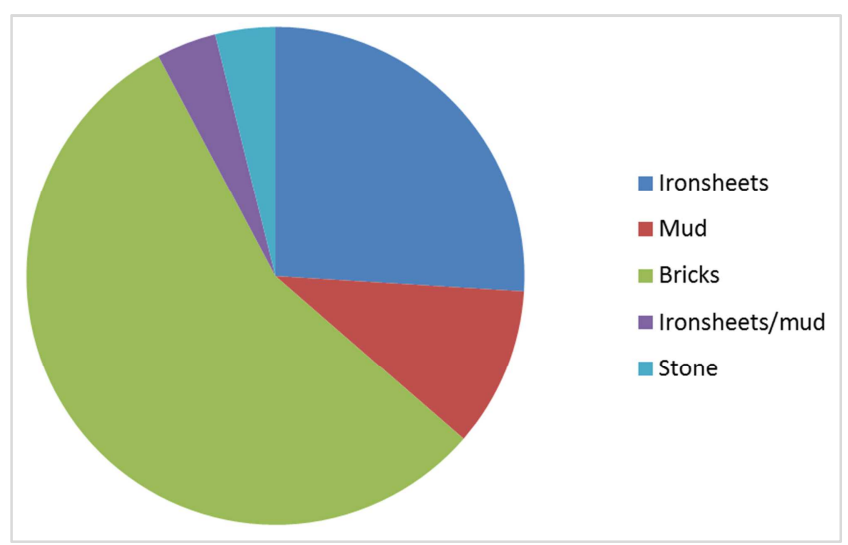

Figure 2. Distribution of construction materials in the study area.

Awareness of EPS is shown in Figure 3. The highest awareness of EPS use was in Kisumu, followed by Nakuru and the last was Eldoret. The mean percentage awareness in the three towns was $43.6 \%$. This showed that majority of people in the low income areas of the three towns were not aware of EPS. This agrees with [12], who pointed out that inadequate professional and public awareness had resulted in low uptake of EPS technology as majority of engineers are still designing houses using stone and mortar technology. Another reason for low awareness was attributed to lack of factories producing EPS in the three towns. All the factories are located in the Capital City of Nairobi. Therefore, if factories are constructed in these towns, the level of awareness is expected to go up. Another problem for lack of awareness could be attributed to lack of skilled masons to construct houses made of EPS.

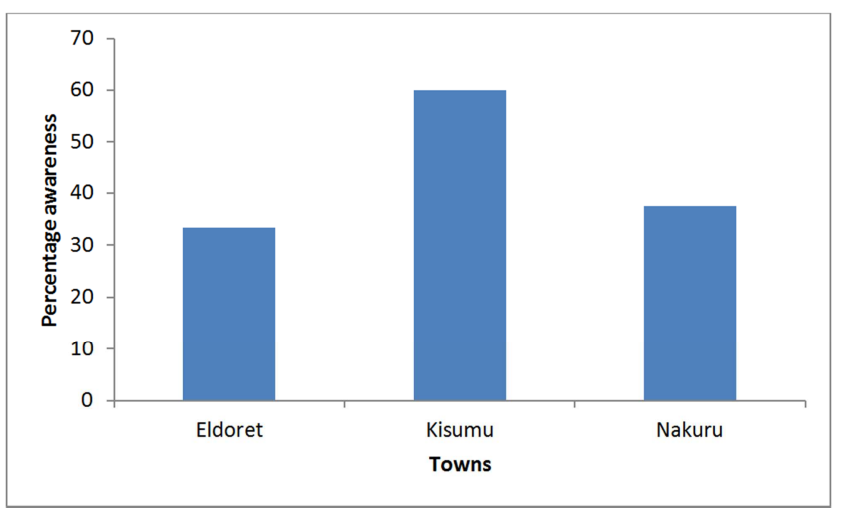

Figure 3. Awareness of EPS in the study area.

Moreover, $98.7 \%$ of the respondents agreed to stay in a house made of EPS. The few people who did not agree to live in EPS houses doubted the strength and durability of EPS when compared to blocks or bricks. This problem could be addressed if more awareness is conducted.

The research revealed that more than $80 \%$ of respondents were not comfortable in the houses they were currently staying and they needed some form of improvement. This was demonstrated by the fact that $94.8 \%$ were ready to pay more if their current living conditions were improved by their landowners.
The number of rooms in a given plot ranged from as low as 3 rooms in Eldoret to a high number of 30 in Kisumu. The average number of more than 10 rooms per plot meant that these low income areas were overcrowded, Kisumu in particular. This congestion could be reason why some respondents were not comfortable with the current living conditions.

The lowest rent per room was observed in Eldoret and highest in Kisumu. The average rent was lowest in Eldoret and highest in Kisumu. The high rent observed in Kisumu was because of the overcrowding which meant that many people were scrambling for the brick walled houses as they searched for comfortable living.

Cost of building depended on the walling materials. The most expensive rooms were those made of bricks or stones at KES. 500,000. This value is close to KES. 600,000 per room [9]. Since most of the rooms have an equivalent area of 20 $\mathrm{m}^{2}$, then such rooms cost KES. 25,000 per square metre. To construct a mud house the least amount was KES. 35,000 meaning that mud houses cost KES. $1,750 / \mathrm{m}^{2}$. For iron sheet house the least amount was KES. 100,000 translating to KES. $5,000 / \mathrm{m}^{2}$ to construct a house with walls made of iron sheets.

\section{Conclusion}

Brick as a walling material was the most used in the three towns. The least used walling material was stone. $40 \%$ of respondents lived in houses made of mud/iron sheets walling. The cost of building a stone building was the most expensive and mud house being the least expensive. Cost of renting rooms was low in Eldoret and highest in Kisumu town. Kisumu Town respondents were more aware of EPS than the other two towns. Almost all the respondents would stay in a house made of EPS. This research did not look at the distance to the source of building materials which affects the preference and use of the walling materials. This is recommended for future research.

\section{Acknowledgements}

The authors would like to thank the University of Eldoret for awarding them research funds.

\section{References}

[1] Centre for Affordable Housing Finance in Africa (2019). Assessing Kenya's affordable Housing Market 1-39.

[2] Diwakar, V. and A. Shepherd (2018). Understanding Poverty in Kenya. A Multidimensional Analysis report. Chronic Poverty Advisory Network. Overseas Development Institute in London.

[3] Van Noppen, A. (2012). The ABC's of Affordable Housing in Kenya.

[4] Government of Kenya (2007). Kenya Vision 2030 (The Popular Version). Page 23. 
[5] World Bank Group 2017. Kenya Economic Update of April 2017 Edition No. 15. Housing Unavailable and unaffordable.

[6] Government of Kenya (2010). The Constitution of Kenya. Government Printer, Nairobi.

[7] (http://www.president.go.ke/). Accessed on 19. June 2019.

[8] http://architecturekenya.com/much-will-building-costconstruct-kenya/.

[9] Association of retirement benefit scheme ARBS. 2018.500,000 Affordable House Programsset (http://www.president.go.ke/). Accessed on 19.june 2019.

[10] Jayanth, M. P., and S. M. Sowmya (2018). Experimental Study on replacement of coarse aggregates by EPS beads in concrete to achieve lightweight concrete. International Research Journal of Engineering and Technology. Volume 5 (7): 610-616.
[11] Lee, J. A., Kelly, H., Rosenfeld, A., Stubee, E., Colaco, J., Gadgil, A., Akbari, H., Norford, L. and H. Van Burik (2006). Affordable, Safe Housing Based on Expanded Polystyrene foam and Cementitious coating. Journal of Material Science. 101007/s1083-006-0223-4.

[12] Ngugi, H. N., Kaluli, J. W. And Z. A. Gariy (2017). Use of Expanded Polystyrene Technology and Materials Recycling for building Construction in Kenya. American Journal of Engineering and Technology Management. 2 (5): 64-71.

[13] Kenya National Bureau of Statistics (2019). 2019 Kenya Population Housing and Census. Volume 1: Population by County and Sub County.

[14] Nyagero, J., Kimani, B. and L. Ikamari (2012). Knowledge, attitude and practices on jigger infestation among household members aged 18 to 60 years: case study of a rural location in Kenya. Pan Afr. Med J. 2012; 13 (Supp 1): 7.

[15] Lysaght (2017). Roofing and Walling Installation Manual. 